Martina Malešič

\title{
Z Vzhoda na Zahod - leto 1948 in njegovi odmevi v slovenski arhitekturni publicistiki
}

\author{
Ključne besede: socialistični realizem, modernizem, slovenska arhitektura, \\ arhitekturna publicistika
}

DOI: $10.4312 /$ ars.9.2.106-121

\section{Uvod}

Spor z Informbirojem in izstop iz vzhodnega bloka leta 1948 je Jugoslaviji prinesel epohalne spremembe na področju zunanjepolitičnih odnosov, notranjepolitične ureditve, gospodarstva in družbe. Vse to je močno odsevalo tudi na kulturnem področju. Sovjetski socialistični realizem, ki je služil kot model prvih povojnih let v jugoslovanski likovni umetnosti, literaturi, gledališču in glasbi, je po letu 1948 vzporedno z rahljanjem kulturnih vezi s Sovjetsko zvezo počasi izgubljal svojo moč. Njegovo mesto so $\mathrm{v}$ začetku petdesetih let ponovno zapolnile modernistične težnje, ki so bile v prvih povojnih letih predmet ostre kritike.

Kratko obdobje od konca 2. svetovne vojne do leta 1948, do izstopa Jugoslavije iz vzhodnega bloka, je v literaturi najpogosteje izpuščeno ali opisano kot kratka avantura slovenske arhitekture, ki se je hitro iztekla in ni pustila bistvenih sledi, kot njeno hipno iztirjenje iz utečenih tirov prevladujočega modernističnega diskurza. ${ }^{1}$ Nenadno

1 Pregledi slovenske arhitekture 20. stoletja se le mestoma ustavijo pri t. i. socialističnorealističnem obdobju. Fran Šijanec mu določi značaj prehodnega obdobja in projekte iz teh let opiše bolj kot mešanico različnih oblikovnih načel (Šijanec, 1961, 474-478). Stane Bernik v svojih pregledih opozarja predvsem na Plečnikov vpliv v povojnih težnjah k monumentaliziranju arhitekturnega izraza, ki so se po njegovem mnenju izrazile pri večini takrat dejavnih arhitektov in trajale vse do začetka petdesetih let. Poleg tega zagovarja tezo, da je bila povojna monumentalnejša govorica $v$ osnovi potomka predvojnega funkcionalizma in da je prav zaradi tega lahko vztrajala tako dolgo (Bernik, 1992, 31-36). Bernik zagovarja idejo kontinuirane osi modernizma, ki je 2. svetovna vojna in "arhitektura nove socialistične dobe " nista prekinili (Bernik, 2004, 100-102). Zato je razumljivo, da kljub dobremu poznavanju povojnega arhitekturnega dogajanja Bernik v svojih besedilih svojih misli dodatno ne argumentira in omenjenih del ne obravnava. In zato tudi ni nenavadno, da je na razstavi novejše slovenske arhitekture, ki jo je postavil leta $1968 \mathrm{v}$ Moderni galeriji, z izjemo Ravnikarjevega načrta za centralno pošto zaradi »akademizma« izločil projekte prvega desetletja. Na to leta 1975 v oceni razstave opozori Nace Šumi: »Razstava naj pokaže vzpon tiste povojne arhitekture pri nas, ki se je na široko odprla svetu [...], medtem ko je bilo prvo desetletje povojne stavbarske kulture zaradi »akademizma« izločeno. Posredno je bilo izločeno vse tisto, kar vzdržuje formalno tradicijo Plečnikove arhitekture (Šumi, 1975, 132-136). Ostali pregledi slovenske moderne arhitekture obravnavano obdobje omenijo le posamično ali se ga popolnoma ognejo. Edini, ki se 
navdušenje nad sovjetskimi modeli, izraženo v slogu, ki je mestoma kazalo znake socialističnega realizma, je po letu 1948 počasi izzvenelo. Petdeseta leta so prinesla ponovni zagon modernizma, ponovno vrnitev k zgledom Le Corbusiera in Bauhausa iz časa med obema vojnama. Moderna arhitektura kot prevladujoči arhitekturni slog Zahoda je postala pomembno orodje za izražanje politične situacije Jugoslavije, njene ločitve od držav vzhodnega bloka in povezovanja z zahodnim. Arhitektura je postala vidni znak jugoslovanske umestitve v konstelacijo svetovnih sil v času hladne vojne.

Razvoj dogodkov - prehod v socialistični realizem, njegova postopna odklonitev po letu 1948 in ponovna obuditev modernizma - kljub navidezni jasnosti ni potekal tako črno-belo, ne v teoriji ne v praksi. Zato je tudi njegova umetnostnozgodovinska obravnava toliko bolj zapletena. Že v glavnem mestu Jugoslavije, Beogradu, kjer se je gradilo največ in so bile potrebe po sledenju jasnim načelom najizrazitejše, je to obdobje polno nejasnosti in netočnih opredelitev, kaj od načrtovanega naj bi bilo modernistično in kaj grajeno v novem, »sovjetskem « slogu. ${ }^{2} \mathrm{~V}$ slovenskem primeru je zaradi manjšega merila in manjših investicij $v$ večje javne projekte prisotnost teh načel še težje izsledljiva. Interpretacijo, kje se »novi« slog v projektih izraža, dodatno otežuje slovenska posebnost močnega Plečnikovega vpliva, ki na prvi pogled briše meje med tistim, kar je nastalo $\mathrm{v}$ profesorjevi maniri, in dejanskimi sovjetskimi zgledi. ${ }^{3}$ Prav zaradi pomanjkanja tvornega gradiva arhitekturne produkcije je analiza tega obdobja $\mathrm{z}$ namenom interpretacije in ne le širšega vpogleda v problematiko izredno težka. Zato se prispevek izogne analizi dejanskega načrtovanja in poskuša opisanemu dogajanju slediti $\mathrm{z}$ vpogledom $\mathrm{v}$ sočasno slovensko arhitekturno publicistiko. Osredotoča se predvsem na izbrana besedila, ki se odzivajo na dinamične preobrate znotraj arhitekturne stroke, pogojene s spreminjajočimi se družbenimi razmerami. Na takšen način lahko jasno spremljamo, kako se je v kratkem časovnem obdobju od leta 1945 do začetka petdesetih let, glede na družbeno-politične razmere, spreminjalo sprejemanje in razumevanje socialističnega realizma in sovjetske arhitekture na eni ter modernizma in zahodne arhitekture na drugi strani. Kot bo razvidno iz pregleda arhitekturnega pisanja, samo leto 1948 ni pomenilo stroge ločnice, temveč je prehod potekal postopoma. Šele začetek petdesetih let je prinesel dokončen zaton

ga loti podrobneje, je Fedja Košir v knjigi o razvoju arhitekturne misli na Slovenskem. Obdobju slovenske različice socialističnega realizma nameni posebno poglavje z naslovom $V$ novem svetu ali intermezzo socialističnega realizma (Košir, 2007, 134-154). Analize pisanja tega obdobja se loti zelo vestno, s pregledom vsega, kar je bilo v tem času izdanega, celoto pa opremi s strogo kritiko. $\mathrm{V}$ naslednjih poglavjih opozori na prve korake t. i. »streznitve« in prehod v ponovno obuditev modernizma, za kar si prizadeva tudi avtoričin članek.

2 Več o tem npr.: Kulić, 2005; Kadijević, 2007.

3 Vpogled v opisano situacijo najbolj slikovito prikaže Zbornik oddelka za arhitekturo na univerzi $v$ Ljubljani 1946-1947, kjer so na enem mestu zbrani tako izdelki iz Plečnikovega seminarja kot projekti za natečajne rešitve za zvezno partijsko palačo in opero v Beogradu, muzej NOB, natečajne rešitve za prezidij in skupščino LRS, natečaj za novo centralno pošto v Ljubljani itd. (Zbornik, 1948). 
socialističnega realizma in ponovno obuditev modernizma, ki je v ozadju vztrajal še iz časa med obema vojnama.

\section{Socialistični realizem v prvih letih »novega sveta«}

Po zaključku 2. svetovne vojne, ko je komunistična partija prevzela oblast, Jugoslavija pa je postala del vzhodnega, komunističnega bloka, je sovjetski družbenopolitični model prevladal na vseh družbenih področjih - od ustave do kulturne politike. Notranjepolitično prizorišče je določil monopol komunistične partije, gospodarstvo je postalo plansko in centralizirano, kulturna produkcija pa se je podredila idejnim načelom vladajoče stranke ter prišla pod nadzor t. i. agitpropa. ${ }^{4}$ Ta je vzpostavil monopol socialističnega realizma na vseh področjih umetniškega ustvarjanja (Gabrič, 2008, 250). Komunistična partija je svoj kulturnopolitični program prilagodila sovjetskemu (Gabrič, 1991, 479). Kulturna ustvarjalnost je vse bolj dobivala poteze, ki so jih oblikovali v Sovjetski zvezi. Prav tako se je tudi kulturno sodelovanje začelo predvsem enostransko usmerjati proti Sovjetski zvezi in drugim vzhodnoevropskim državam. ${ }^{5}$ Sovjetska kultura je prevladovala na vseh področjih, v leposlovnih prevodih, gledališčih, kinematografih in šolstvu (Gabrič, 2008, 251-253). Boris Ziherl, slovenski politik in najpomembnejši kulturni ideolog tega časa, je v številnih člankih prevzel vlogo glavnega zagovornika socialističnega realizma po sovjetskem zgledu in strogo obsodil izme 20. stoletja (Gabrič, 1991, 486). Na II. kongresu Društva za kulturno sodelovanje Jugoslavije s Sovjetsko zvezo leta 1948 v Beogradu je slikovito opisal vodilne ideje tega časa. Ugotavljal je, da na svetu obstajata dve kulturi, »na eni strani kultura umirajočega, gnilega sveta, sveta kapitalizma, na drugi strani kultura rastočega sveta, sveta, polnega življenjske volje in radosti, sveta socializma« (Gabrič, 1991, 589).

V prvih povojnih letih so slovenski arhitekti tako kot arhitekti ostalih jugoslovanskih republik iz ideoloških razlogov arhitekturo Sovjetske zveze sprejeli

4 Agitprop (okrajšava za agitacijo in propagando) je kot poseben organ komunistične partije skrbel za organizacijo in nadzor celotne kulturne produkcije v državi. Sicer je mreža agitpropov obstajala že prej, a je šele po 1.1945 začela delovati bolj organizirano in neposredno vodeno iz centralnih ter pokrajinskih partijskih organov. Glavna naloga agitpropov je bila ideološki dvig partijskega kadra ter pravilna ideološka in politična vzgoja širokih ljudskih množic. Več o agitpropu: Gabrič, 1991.

$5 \quad$ V prvih povojnih letih se je sovjetski vpliv krepil tudi s pomočjo neposrednih stikov. V Jugoslaviji je gostovalo veliko sovjetskih umetniških skupin ter delegacij političnih in kulturnih delavcev. Velik odmev je med drugim vzbudila razstava sovjetskih slikarjev, ki je najprej gostovala v Beogradu, novembra 1947 pa še v Moderni galeriji v Ljubljani. Slovenske publikacije so vključevale vedno več prevodov sovjetskih estetsko-teoretskih člankov, leta 1946 sta izšla tudi prevoda dveh knjig, Socialistični realizem L. Timofejeva in Referat o revijah "Zvezda" in "Leningrad" A. A. Ždanova. Poleg tega je bilo junija 1945 ustanovljeno Društvo za kulturno sodelovanje Slovenije s Sovjetsko zvezo (Gabrič, 1991, 546-549, 588). 
kot vzor, ki mu je treba slediti. Zvezno vsejugoslovansko revijo Arhitektura ${ }^{6}$ so v tem času preplavile podobe sovjetske arhitekture in prevodi sovjetskih teoretskopolemičnih tekstov. Vendar pa kljub močni prisotnosti jugoslovanskim arhitektom v predstavljenih sovjetskih zgledih ni uspelo razbrati modela za svoje delo. Zato so se začele množiti razprave o tem, kakšna naj bi bila ta nova jugoslovanska arhitektura. Mnenja so bila različna in redko enoglasna. Edina stalnica pa je bila naklonjenost klasičnemu arhitekturnemu jeziku in obsodba medvojnega modernizma kot dekadentnega buržoaznega formalizma. Vladimir Kulić in Maroje Mrduljaš (2012) v monografiji o jugoslovanski arhitekturi v času socializma poskušata ta šum v prenosu sovjetskega zgleda pojasniti na več načinov. Prvi razlog vidita v specifičnem razvoju jugoslovanske arhitekturne stroke. Arhitekturno elito, ki je prevzela glavno vlogo po vojni, so večinoma sestavljali vodilni modernisti in njihovi študentje. Mnogi od njih so zasedli vodilne položaje predvsem zaradi svoje zavzetosti v narodnoosvobodilni vojni. ${ }^{7}$ Drugi, še pomembnejši razlog najdeta $v$ tem, da arhitektura socialističnega realizma nikoli ni bila natančno opredeljena. Celo v Sovjetski zvezi to teoretsko vprašanje nikoli ni bilo rešeno. Opredelitev socialističnega realizma se je ukvarjala predvsem z vsebino, koncept sloga pa je bil sekundarnega pomena (Golomstock, 1990, 270). Za razliko od slikarstva in literature ${ }^{8}$ ni bilo jasno, kakšna naj bi bila »realistična" arhitektura in kako naj bi izražala svojo socialistično vsebino (Kulić, Mrduljaš, Thaler, 2012, 33-34). Navodila so arhitekti, tako kot drugi umetniki, razbirali posredno, iz govorov politikov, kritik in napadov $\mathrm{v}$ časopisih. Tako se je sčasoma oblikovala osnovna pojavnost sovjetske arhitekture, slog, ki pa mu lahko vsaj v grobem določimo ohlapno definicijo. Arhitektura, ki jo je zahteval socialistični realizem, je morala na prvem mestu odsevati veličino obdobja izgradnje komunizma (Golomstock, 1990, 270-280). Veličino ustvarjajo monumentalni kolosi, sestavljeni iz masivnih stavbnih volumnov, postavljeni na velike trge in ob široke prospekte. Učinek še dodatno poudarjajo retorični efekti fasade, reliefi, napisi, poslikave, parole in kipi. Okras, ki je običajno prisoten, je

6 Revija Arhitektura je kot zvezna vsejugoslovanska revija izhajala od leta 1947 do 1949 v Zagrebu (Savez društava inženjera i tehničara FNRJ). Nadaljevala se je v Urbanizam i arhitektura; časopis za arhitekturu, urbanizam i primjenu umjetnost (1950-1951), ta pa v Arhitektura: stručni i znanstveni časopis Udruženja hrvatskih arhitekata od l. 1952 dalje.

7 Takšne okoliščine so bile na ljubljanski šoli za arhitekturo še posebej očitne. Menjava ideoloških izhodišč je na šoli sprožila zamenjavo generacij. Vodilni osebnosti Ivan Vurnik in Jože Plečnik sta se po vojni umaknila novemu rodu univerzitetnih profesorjev, Edu Mihevcu in Edvardu Ravnikarju, ki sta bila dejavna v NOB in obenem vodilna funkcionalista. Fedja Košir $(2007,136)$ na tem mestu opozarja tudi na svojevrsten paradoks slovenske situacije: Plečnik, ki je bil s svojim arhitekturnim izrazom na neki način »najbolj na liniji« s sovjetskim (seveda le v slogu in ne v ideologiji), je bil po vojni odrinjen v izolacijo svojega seminarja.

8 Socialistični realizem kot umetnostna metoda tudi sicer za ostale umetnostne zvrsti ni bil nikoli uradno definiran. Vendar pa, kot predpostavlja Pavlinec (2004, 222-223), lahko iz njegove definicije s 1. zveznega kongresa sovjetskih pisateljev 1. 1934 v Moskvi (Golomstock, 1990, 86) razberemo, kakšna naj bi bila njegova vsebina (forma naj bi bila drugotnega pomena). Zato so lahko umetnostne zvrsti, ki imajo sredstva, da to vsebino upodobijo (likovna umetnost, leposlovje, film), bistvu socialističnega realizma sledile precej lažje kot arhitektura. 
pogosto prevzet iz ljudske arhitekture, izhaja torej iz ljudstva. Druga predpostavka je, da je bila socialističnorealistična arhitektura za razliko od avantgardnega modernizma dedič univerzalne kulturne tradicije, predvsem klasične antike, stare Grčije in Rima (Golomstock, 1990, 290). Vse to določi njeno obliko: jasnost zasnove, klasična načela oblikovanja, simetričnost kompozicije, monumentalnost in uporaba klasičnih stavbnih elementov, kot so stebri, zatrepi in frizi.

Glede na opisano nedefiniranost socialističnorealistične arhitekture v njeni matici si lahko predstavljamo, kako negotovi so bili jugoslovanski arhitekti, ko so brali številne prevode sovjetskih teoretikov ali si ogledovali sovjetske projekte. Ilustraciji takšne nedorečenosti naj služi knjižica $\mathrm{z}$ naslovom Umetnostni problemi sovjetske arhitekture, slovenski prevod poročila podpredsednika akademije arhitekture ZSSR na njenem četrtem zasedanju, A. G. Mordvinova (1946). Z vpogledom v njeno vsebino lahko dobimo vsaj malo predstave, kakšna besedila so v tem obdobju brali slovenski arhitekti. ${ }^{9}$ Mordvinov se v tej mali brošuri ukvarja $\mathrm{z}$ vprašanjem, ali in kdaj je arhitektura umetnost. Opozarja, da mora arhitektura zadovoljevati estetske potrebe ljudstva, obenem pa mora vzbujati zavest njegove moči ter vrednosti njegove dežele. Arhitektura mora izpolniti tako svojo utilitarno kot umetnostno funkcijo. Mordvinov na tem mestu vključi kritiko modernizma kot tistega, ki teži le k utilitarni funkciji, zanika dekor in ornament ter tako povzroča škodo mestom in vasem ter razvoju obrtništva in domače obrti: »[...] pri nas sta dolga leta gospodovala konstruktivizem in primitivizem, ki sta dovedla do negiranja arhitekture kot umetnosti. Posledica takega odnosa do arhitekture je, da so se nekatera naša mesta napolnila z dolgočasnimi škatlami« (Mordvinov, 1946, 10). Spodbuja tudi uporabo narodnih ljudskih motivov v novi arhitekturi. »Z uporabo nacionalnih oblik bomo dosegli v arhitekturi ljudskih republik pestro barvno bogastvo, humanistični klasični karakter $\mathrm{v}$ tej arhitekturi pa je tisti skupni princip, ki varuje njene svojske poteze in posebnosti« (Mordvinov, 1946, 16). Za Mordvinova sta ključni sestavini nove arhitekture socialistična vsebina in klasična načela, ki s svojim humanističnim, vseljudskim značajem tvorijo zvezo z vsem, kar je kvalitetnega v preteklosti človeštva. Samo taka tvorna osnova bo po njegovem mnenju omogočila arhitekturo, socialistično po vsebini in narodno po obliki (Mordvinov, 1946, 17). Glavne misli iz brošure sicer niso bile neposredno prenesene v pisanja slovenskih avtorjev, lahko pa zasledimo podobno dikcijo, besednjak, navdušenje nad dekorjem in kritiko modernizma.

Slovenski arhitekti so bili $\mathrm{v}$ prvih povojnih letih vključeni $\mathrm{v}$ uredništvo vsejugoslovanske revije Arhitektura, vendar pri sami reviji niso imeli veliko besede, za slovenske prispevke pa je pogosto zmanjkalo prostora. Zato so raje pisali v arhitekturi

9 Fedja Košir $(2007,137)$ trdi, da naj bi imel to brošuro v svoji knjižnici med drugim tudi slovenskobosanski arhitekt Dušan Grabrijan. 
namenjene kolumne splošnih časopisov, kot sta bila Slovenski poročevalec in Novi svet. Ključni pisci teh prvih povojnih let so bili Dušan Grabrijan ter mlada Marjan Tepina in Edvard Ravnikar. Sprva je bila glavna tema obnova domovine, vedno glasnejše pa je postajalo vprašanje arhitekturnega izraza teh novih nalog. Marjan Tepina (1946) začne svoj članek Načrtnost terja nove metode projektiranja s hvalo razcveta sovjetskega gospodarstva po revoluciji. Ključ za njegov uspeh vidi predvsem v socialistični ureditvi ZSSR. V nadaljevanju se razgovori o novih nalogah, ki jih arhitektom nalaga novi čas, o novem načinu dela in poteku projektiranja, omeni pa tudi potrebo po novem slogu, lastnem tej novi dobi (Tepina, 1946, 132-135). Sloga kot takega sicer ne opredeli, pa tudi njegovega izvora vsaj neposredno ne izda, vendar ga kljub temu mimogrede omeni:

Ne moremo zatajiti, da so naši inženirji pred vojno videli v Nemčiji vir vsega tehničnega znanja in skušenj, da so ob tem mnogokrat podcenjevali svoje lastne sile. Ob globokih spremembah v značaju naše države se vrača vsepovsod zaupanje $\mathrm{v}$ lastne sile in sposobnosti. $\mathrm{S}$ tesno povezavo $\mathrm{z}$ našo veliko zaščitnico ZSSR se odpirajo viri skušenj in znanja vse drugih dimenzij (Tepina, 1946, 135).

Naslednje leto je za revijo Novi svet članek prispeval Edvard Ravnikar. V prispevku Maršal Tito našim arhitektom (Ravnikar, 1947) obnovi ključne točke Titovega nagovora ob natečajih za reprezentančne zgradbe Novega Beograda. Natečaji za zgradbo CKKPJ, sedež vlade FLRJ in reprezentančni hotel so sprožili vprašanja, kot so zrelost in tehnična zmogljivost jugoslovanske arhitekture, vprašanje njenega odnosa do novega družbenega stanja in novih oblik ter nenazadnje njenega izraza, nove forme in monumentalnosti. Na tej točki je postala razprava o novem slogovnem izrazu vedno bolj konkretna. $\mathrm{O}$ teh vprašanjih je Tito spregovoril na srečanju $\mathrm{z}$ udeleženci natečaja po njegovem zaključku. Kakšna naj bi bila arhitektura nove dobe, je prikazal predvsem na primeru zgradbe CK: »Ne smemo iskati in suženjsko posnemati preživelih oblik iz preteklih dob, še manj pa trenutnih modnih poskusov, ki so prehodni. Ustvariti moramo močno, živo formo, ki bo lastna samo arhitekturi nove Jugoslavije« (Ravnikar, 1947, 304). Na tem mestu omenja le potrebo po novem arhitekturnem jeziku, ki bi izražal nacionalno identiteto Jugoslavije. V nadaljevanju postane že bolj konkreten:

Zgradba mora imeti glavni poudarek že v svoji legi na konici levega brega Save v osi Donave. Sama kompozicija mora v tlorisu in oblikovanju forme zunanjščine izražati vso dinamiko, ki je značilna za to vodilno ustanovo. Izraziti jo mora v plemenitem materialu. Vtis celote naj bo elementaren. [...] Za zgradbe nove Jugoslavije ne zadošča samo izraz, ki ga dajo lahko abstraktne forme arhitekture, stavbe morajo pripovedovati več, zato mora 
arhitekturi priti v pomoč kiparstvo. V največji možni meri se mora v celotno zasnovo pritegniti plastični okras, kiparstvo, kot najvišja stopnja likovnega izraza. Moč kiparske simbolike mora izraziti naše nove notranje in zunanje odnose. Plastika naj razen sile Partije izraža še naša čustva do vzhoda in zapada (Ravnikar, 1947, 363).

Povzetek govora se zaključi s kritiko zahodne arhitekture in modernizma:

Naša arhitektura bo morala že v bližnji bodočnosti reševati ogromne naloge, tehnične in reprezentančne, in nas bo prisilila, da tudi tukaj postanemo močni in neodvisni ustvarjalci in ne posnemalci, kajti naši dosedanji vzori na zapadu s svojo utopičnostjo, fantastiko in formalizmom, ki so posledica družbenega zastoja, nam ne bodo mogli nuditi ničesar več. Za nas dobivajo močna umetniška dela velikanski pomen, medtem ko so na zapadu nepotrebna. Na naših arhitektih pa je, da spremene pobude maršala Tita v umetniška dejanja, ki jih ne more nadomestiti nikakršno drugo prizadevanje. Dani so pogoji, kot so bili redki v zgodovini arhitekture, ko so veliki državniki ustvarjali osnove za velika dela arhitekture (Ravnikar, 1947, 365).

Iz besedila sicer ni popolnoma razvidno, ali takšna kritika modernizma prihaja iz arhitektovih ali maršalovih ust, a zagnanost $\mathrm{v}$ načinu njenega podajanja vsekakor nakazuje Ravnikarjev prehod v bran novega arhitekturnega jezika. V prispevku o novi državni operi v Beogradu se ob trditvah vsebinske narave, da je opera po svojem izvoru zgradba z izrazito družbenoideološkim značajem in da mora biti nova opera res ljudska, dostopna vsem, dotakne tudi njene oblike: „Opera naj bo med glavnimi arhitektonskimi lepotami Novega Beograda, v celoti naj bo monumentalna, svobodna, pa ne modna, in bogata $\mathrm{v}$ skulpturnih sestavinah. Vsa naj bo obložena s kamnom, notranja gradnja pa naj bo železobetonski skelet« (Ravnikar, Nova, 1948, 307). Ravnikar sicer mimogrede in brez potrebnih olajšav, a jasno obnovi ključne maršalove zahteve za stavbo CK: monumentalnost, nemodnost in kiparski okras.

Leta 1948 je po Jugoslaviji potovala razstava o sovjetski arhitekturi. Junija je bila postavljena v Moderni galeriji v Ljubljani. Ob tej priložnosti je Edvard Ravnikar v reviji Novi svet napisal poročilo o tej razstavi, ki je sovjetski arhitekturi zelo naklonjeno (Ravnikar, Razstava, 1948). ${ }^{10}$ Hvali njeno obliko in vsebino, kako zna zadostiti družbenim potrebam in se zaveda svojih realnih nalog, $\mathrm{v}$ nasprotju $\mathrm{z}$ zahodno arhitekturo, ki arhitekturo obravnava le kot stvar načina. Razstava je po njegovem mnenju

10 Revija Novi svet je bila v letih 1946-1952 osrednja oziroma poleg Mladinske revije edina slovenska kulturniška revija ter kot taka pod nenehnim ideološkim nadzorom. Njeno pozicijo nakazuje že ime, saj naj bi bila le prevod imena takratne osrednje sovjetske kulturne revije Novij mir. Prav zato Ravnikarjevo besedišče in dikcija ne moreta biti presenečenje, saj v tem kontekstu ni mogel pisati drugače kot Sovjetski zvezi naklonjeno. Več o reviji v: Gabrič, 1991. 
... boleče prikazala kontrast med silo in poletom arhitekturnega snovanja v Sovjetski Zvezi, ki spominja na največje zgodovinske dobe arhitekture, in mračno perspektivo vedno enako nepremagljive brezupnosti v kapitalističnih deželah. Medtem, ko na eni strani grade veliko, čim več in vedno boljše, se mora na drugi strani arhitekt izgubljati v teorijah in v neprestanem ustanavljanju že v naprej obsojenih urbanističnih struj, vedno znova organizirati kongrese brez uspeha in večno odlagati izvedbe perečih socialnih nalog arhitekture (Ravnikar, Razstava, 1948, 612).

Nadaljuje $\mathrm{z}$ opredeljevanjem in na neki način tudi opravičevanjem njenega sloga:

Zaman bi pričakovali, da se bo sovjetska arhitektura približala rešitvam, ki na njih slone naše predstave o zapadni arhitekturi, ker bi to ne ustrezalo niti njenim nalogam, niti njenemu značaju realistične ljudske arhitekture. Sovjetska arhitektura mora brezpogojno uresničevati širok program in to $\mathrm{s}$ sredstvi, ki so ji na razpolago. Če se njen izraz naslanja na klasiko, ima tudi to svoj globok vzrok [...] Ta arhitektura je zrcalo sovjetske stvarnosti in postavlja se vprašanje likovnega jezika, ki ga bosta enako razumela ustvarjalec in gledalec. [...] V Sovjetski zvezi se ne pojavlja prazen eklekticizem, temveč kot nujno izhodišče svojevrstna renesansa grške arhitekture, ki je že tolikokrat v zgodovini arhitekture služila kot izrazna osnova nove družbe [...] Iz sovjetske arhitekture se lahko učimo, kako je treba graditi svojo sodobno kulturo (Ravnikar, Razstava, 1948).

Ob prvem branju izredno preseneti, da Ravnikar tako ostro kritizira zahodno arhitekturo modernizma in z njo svojega učitelja Le Corbusiera, pri katerem se je šolal v tridesetih letih, ter pohvalno piše o eklektični sovjetski arhitekturi. Podobno opazi tudi Košir $(2007,145)$, ki pri laskavih ocenah razstave arhitekture narodov ZSSR zapiše, da "slovenski funkcionalisti, ki so nekoč romali v modernistični Pariz, zdaj zavračajo zahodno moderno arhitekturo in občudujejo sovjetsko renesanso grške arhitekture«. A če beremo pozorneje, opazimo, da se Ravnikar pravzaprav ne opredeli glede sloga. Zapiše le, da je sovjetska arhitektura primerna svojim lastnim razmeram, ne pa, da bi morali projekti slovenskih arhitektov slediti temu zgledu. Prav tako pri kritiki zahodne arhitekture ne kritizira modernizma kot takega, temveč njegove okoliščine, ki preprečujejo, da bi se realiziral v celoti, da bi uresničil »izvedbo perečih socialnih nalog arhitekture«.

Kljub navdušenju nad sovjetsko arhitekturo in povzemanju iz sovjetske literature se besedna zveza "socialistični realizem" prvič pojavi šele v članku arhitektke Mire Kraigher K nekim pripombam o arhitekturi na V. Kongresu KPJ leta 1948: 
Naša bodoča arhitektura bo brez dvoma imela vse značilnosti socialističnega realizma, ki temelji na tehle principih: Njegov subjekt in objekt je svobodni, ustvarjalni človek. Delo je postalo stvar časti. Vera v moč ljudskih množic je temelj optimizmu. Ljubezen, patriotizem do svojega naroda in spoštovanje do drugih ter $s$ tem $\mathrm{v}$ zvezi razvijanje nacionalnih kultur; ne statično gledanje, temveč stremljenje, da se življenje prikaže $\mathrm{v}$ gibanju in razvoju, tisto, kar se danes razvija in kar se razcveta $\mathrm{v}$ bodočnost - skratka, podajati v umetniški obliki vse, kar je značilno za socializem - to je stališče, to je prijem in vsebina sovjetske umetnosti in brez dvoma tudi naše. [...] Tudi mi težimo k preprosti, naravni in jasni obliki - torej ne kulis in prenatrpanosti okraskov, tudi ne razblinjenih form, značilnih za dekadentne izrastke arhitekture zapada; ne enolične, mnogolične naj bodo zato naše forme: Drugačne za industrijo, drugačne za zadružni dom, drugačne za spomenik NOB. S tem smo se približali tretji komponenti arhitekture, ki nas najbolj loči od imperialističnega zapada in s tem že pridobiva na pomenu - to je njena vsebina in idejnost. Vsebina projektiranja je v socializmu bistveno drugačna kot $\mathrm{v}$ kapitalizmu. Zdaj je treba razumeti in rešiti na najboljši način nove, mnogo širše, delovnemu ljudstvu posvečene naloge tudi v arhitekturi (Kraigher, 1948, 780).

Članek Mire Kraigher podaja podobna sporočila kot prispevki ostalih arhitektov, le da so, verjetno zaradi avtoričinega političnega delovanja, obdana s še močnejšim ideološkim zagonom in izbranimi parolami. Bistvo socialističnega realizma je njegova vsebina, za obliko je pomembno predvsem to, da ni podobna dekadentni zahodni arhitekturi.

Sočasno z nanizanimi članki sta leta 1948 izšli publikaciji dveh ključnih arhitekturnih središč tega časa. Na Oddelku za arhitekturo Univerze v Ljubljani so izdali zbornik dvoletnega dela po novem učnem načrtu (Zbornik, 1948), na Projektivnem zavodu LRS Ministrstva za gradnje pa poročilo o delu Projektivnega zavoda LRS za leti 1945 in 1946 z naslovom Urbanizem, arhitektura, konstrukcije. Direktor zavoda Domicijan Serajnik se v uvodu ne opredeli ne do socialističnega realizma ali sovjetske arhitekture ne do izraza v publikaciji objavljenih projektov, vendar se iskreno veseli monumentalnosti prihajajočih izvedb (Urbanizem, 1948, 5). Druga publikacija Zbornika oddelka za arhitekturo na univerzi v Ljubljani 1946-1947 je prav tako kot prva bolj zanimiva zaradi grafičnega kot pa tekstovnega gradiva. V njej so poleg drugih študentskih del namreč objavljeni številni projekti, ki so nastali za natečaje na slovenski in jugoslovanski ravni in ki kažejo določene socialističnorealistične elemente, na primer za zvezno partijsko palačo in opero $\mathrm{v}$ Beogradu, muzej NOB, natečajne rešitve za prezidij in skupščino LRS ter za novo centralno pošto v Ljubljani. Uvodnik v 
zborniku, ki sta ga uredila Marjan Mušič in France Ivanšek, omenja potrebo po zavesti o odgovornosti in velikih nalogah arhitekture na »novi poti«, izpostavlja tudi trdne ideološke osnove, na katerih se razvijajo novi odnosi arhitekture do družbene situacije. Omenja tudi nov izraz in nove načine dela, ki jih zahteva nov čas. »Stremimo za tem, da izločimo vse kvarne usedline prejšnjih razmer, ki bi mogle zavirati razvoj [...]. Naša nova arhitektura mora postati napredna pridobitev ljudske kulture. Nove oblike morajo izražati nove ideje in nove družbene odnose« (Zbornik, 1948, 11-12). Vendar sovjetskih zgledov ne omenja, poleg tega pa tudi ne komentira novega arhitekturnega jezika predstavljenih projektov.

\section{Leto 1948 in počasna vrnitev modernizma}

Spomladi 1948 so se odnosi med Jugoslavijo in Sovjetsko zvezo začeli krhati. Sporu in izstopu iz Informbiroja je sledila zaostritev razmer, ki so jih rešile šele spremembe $\mathrm{v}$ petdesetih letih: uvajanje samoupravljanja, postopna decentralizacija in pomoč z Zahoda (Repe, 2004). Kljub sporu pa Gabrič (1991, 587-592; 2008, 254) opozarja, da je do prvih opaznejših sprememb v odnosu do sovjetskega kulturnega modela prišlo šele leta 1949. Navezava kulturnih stikov s Sovjetsko zvezo se je sicer počasi rahljala, vendar je socialistični realizem še naprej ostal gonilna sila ideološko pravilne kulturne dejavnosti. Konec leta 1948 je kljub sporu Jugoslavija na vsak način hotela dokazati, da je na pravi poti in pravilni kulturni usmeritvi. Šele leto 1949 je prineslo spremenjen pogled na sovjetsko kulturo. Agitprop je zahteval spremembe repertoarja v ustanovah, društvih in medijih, proti koncu leta 1949 pa so jugoslovanski mediji začeli objavljati vse ostrejše kritike sovjetskega družbeno-političnega sistema. Dodatne spremembe je sprožil III. plenum centralnega komiteja KPJ, kjer so se nakazale težnje po decentralizaciji kulturne politike in zmanjšanju administrativnega aparata ministrstev. Leto 1948 tako ni pomenilo prelomnice v slovenski kulturni dejavnosti. Ta se namreč ni spreminjala, saj je leta 1948 tudi kulturna politika ostala nespremenjena. ${ }^{11}$ Dokončen obračun s starimi načeli socialističnega realizma je prineslo šele leto 1952, s 3. kongresom Zveze književnikov Jugoslavije v Ljubljani (Gabrič, 1991, 587-592).

Po letu 1948 je arhitektura Sovjetske zveze počasi zapustila strani slovenskega arhitekturnega časopisja. Prostor v slovenski publicistiki je zapolnila analiza in kritika arhitekture in urbanizma prvih povojnih let, poleg tega pa se je vedno bolj vzpostavljalo vprašanje lastnega nacionalnega sloga. Podobno kot na širšem kulturnem področju

11 Takšno zapoznelo reakcijo Gabrič $(1991,591)$ razloži predvsem kot odsev gospodarskih razmer, v katerih se je znašla Jugoslavija po izstopu iz vzhodnega bloka. Spremembo v pogledih na sovjetsko kulturo vidi predvsem kot posledico splošnega političnega in ekonomskega položaja v Jugoslaviji, saj se je država znašla popolnoma izolirana, v vse slabšem gospodarskem položaju in v nevarnosti intervencije Vzhodnega bloka. 
je tudi v arhitekturnem pisanju kljub prekinitvi vezi s Sovjetsko zvezo socialistični realizem še vedno vztrajal. Vzporedno pa se je počasi začel spreminjati odnos do modernizma. Prvo otoplitev lahko zaznamo v Ravnikarjevem članku ob razstavi arhitekture FLRJ v Moderni galeriji leta 1949 (Ravnikar, 1949, 604-608), v katerem modernizma medvojnega obdobja ne kritizira več $\mathrm{z}$ ideoloških stališč, ampak mu, podobno kot $\mathrm{v}$ oceni razstave sovjetske arhitekture, očita predvsem problematiko njegove izvedbe.

Na dejansko obuditev modernizma in ponovno vzpostavljeno vez z Zahodom je bilo treba počakati šele do začetka petdesetih let. Novembra 1950 je Dubrovnik gostil 1. kongres jugoslovanskih arhitektov, na katerem so na skupni vsejugoslovanski ravni dokončno zavrnili sovjetske modele socialističnega realizma in obenem ponovno vzpostavili modernizem kot državni vsejugoslovanski slog (Kulić, Mrduljaš, Thaler, 2012, 36). Iz poročila, ki je bilo objavljeno v reviji Urbanizam i arhitektura, lahko razberemo, da je bila glavna tema kongresa pregled dela prvih povojnih let. Eden izmed izpostavljenih zaključkov je ocena sovjetske arhitekture kot formalistične, nerealne in nesocialistične, drugi pa zahteva novo, sodobno socialistično arhitekturo, ki bo daleč stran od historičnih slogov Sovjetske zveze ter bo jasno odsevala specifičnost jugoslovanskega političnega in ideološkega projekta (Zaključci, 1950, 5). Referate $s$ kongresa so objavili v zbornikih posamezne republike. Že vsebina slovenskega zbornika $\mathrm{z}$ naslovom Problemi arhitekture in urbanizma LR Slovenije (1950) prikaže preusmeritev pozornosti z vzhodnega na zahodni model. Teme, kot so teoretska vprašanja, vprašanja sloga in novih nalog arhitekture ter potek njene organizacije, zamenja reševanje konkretnih nalog, dobesedno vezanih na izgradnjo socializma. Ravnikar predstavi novo vizijo modernega urbanizma, s poudarkom na decentralizaciji, sledijo prispevki o gradnji stanovanj (Tone Klemenčič, Danilo Fürst), zdravstvenih domovih (Jože Platner) ter industrijski arhitekturi (Miro Gregorič, Niko Bežek). Zadnji prispevek v zborniku je še posebej zgovoren neizpodbiten znak preusmeritve jugoslovanske arhitekture. Dušan Grabrijan je na dubrovniškem kongresu predstavil referat z naslovom Naše orijentalne i savremena kuća (Grabrijan, 1950, 105-115). Razkril je, da je v svojih raziskavah bosanske in makedonske hiše odkril načela, ki so lastna tudi moderni sodobni arhitekturi, v prvi vrsti projektom Le Corbusiera. Boljše dobrodošlice modernizem v jugoslovanski arhitekturi ne bi mogel dobiti! Na prvem zveznem kongresu jugoslovanskih arhitektov je bila moderna arhitektura najprej predstavljena kot pomembna, vredna raziskovanja, poleg tega pa je bil v njenem jedru odkrit arhetip, kontinuiteta uporabe "pravih«, v stoletjih preverjenih pravil gradnje, kar je še dodatno utemeljilo njeno legitimnost. Kot ugotovita Kulić in Mrduljaš $(2012,36)$, je prav recepcija Le Corbusiera tista, ki deluje kot neke vrste lakmusov papir za geopolitično orientacijo Jugoslavije in vzpon 
modernizma med jugoslovanskimi arhitekti. Po letu 1950 se je njegovo ime ponovno začelo pojavljati v svetli luči, še bolj simbolična pa je bila retrospektivna razstava njegovega dela v Jugoslaviji kot ena prvih arhitekturnih razstav po prelomu s Sovjeti. Moderna galerija v Ljubljani jo je gostila maja 1953.

Premik k večji decentralizaciji po letu 1950 je posamezni jugoslovanski republiki omogočil, da je lažje poudarjala in razvijala lastne nacionalne značilnosti, vezane na specifične kulturne in zgodovinske okoliščine. Ustanavljala so se republiška arhitekturna društva, pojavljati so se začela nacionalna arhitekturna glasila. Slovenski arhitekti so leta 1951 predstavili novo slovensko arhitekturno publikacijo, imenovano Arhitekt. Poleg osamosvajanja je revija predstavila jasen znak odprtja slovenske arhitekture proti Zahodu, tako v vsebini (že v prvi številki naletimo na prispevek o švicarski arhitekturi) kot v uvodnih besedah. Napiše jih glavni urednik revije, Ravnikarjev študent France Ivanšek: »Arhitektura se razvija iz družbenih pogojev, iz katerih izhaja, okoriščajoč se pri tem $\mathrm{z}$ napredno domačo in tujo tradicijo in s pridobitvami sodobne arhitekture $\mathrm{v}$ svetu« (Ivanšek, 1951, 1). V besednjaku slovenskih arhitektov tako ni več glasu o grških stebrih, kiparskem okrasu ali monumentalizmu sovjetske arhitekture. Nadomestili so jih izrazi, kot so naprednost, sodobnost in lokalna tradicija.

\section{Zaključek}

Pregled izbranih primerov iz slovenske arhitekturne publicistike od leta 1945 do petdesetih let naj služi kot izhodišče za več zaključkov. Kljub temu, da socialistični realizem Sovjetske zveze $\mathrm{v}$ jugoslovanski in $\mathrm{z}$ njo slovenski arhitekturi ni pustil trajnejšega pečata, je njegova retorika $\mathrm{v}$ prvih povojnih letih močno odmevala $\mathrm{v}$ arhitekturnem časopisju. Leto 1948 ni prineslo jasnega reza. S tem letom sicer pojenja kritika modernizma, formalizma in individualizma zahodne arhitekture. Navdušenje nad sovjetsko arhitekturo, nad njeno monumentalnostjo ter poudarjeno arhitekturno govorico s klasičnimi načeli in kiparskim okrasom pa vztraja še vse do dubrovniškega kongresa leta 1950. Po tej letnici se vzporedno z odpiranjem proti Zahodu vedno bolj vzpostavlja ponoven stik z modernizmom. Še več, sredi petdesetih let, ko slovenska arhitektura doseže suverenost, posamezni arhitekti svojo vlogo pri širjenju socialističnega realizma kolikor je le mogoče zmanjšajo ali celo zanikajo. Edvard Ravnikar in France Ivanšek leta 1955 za glasilo Architects' Year Book napišeta članek o povojni arhitekturi v Jugoslaviji. Prvo povojno obdobje tuji, angleški publiki predstavita na takšen način:

Socialistični realizem (v sovjetskem smislu) je v jugoslovanski arhitekturi izumrl sam od sebe $\mathrm{z}$ odstranitvijo sovjetskega vpliva. Naj dodava, da arhitekti do njega niso gojili prave simpatije.« Nadaljujeta, da »... danes 
lahko s hvaležnostjo rečemo, da je Le Corbusieru uspelo za arhitekturo navdušiti celo generacijo jugoslovanskih arhitektov. Prav iz tega vira se je razvila naša arhitektura. Čeprav je pogosto stereotipna in se med seboj ne razlikuje zadostno ali pa je celo toga in slabo prilagojena našim specifičnim razmeram, nihče ne more oporekati pomembnosti Le Corbusierove vloge $\mathrm{v}$ razvoju naše moderne arhitekture ${ }^{12}$ (Ravnikar, Ivanšek, 1955, 121).

Navedeni članek še bolj kot druga besedila v prispevku prikazuje, kako zapletena in razburkana je bila družbena klima od leta 1945 do začetka petdesetih let, ko so se v kratkem časovnem obdobju zvrstile spremembe izrednih razsežnosti na politični, gospodarski, ideološki in kulturni ravni, ki so bistveno vplivale tudi na posameznika ter njegovo javno in zasebno delovanje. V tem kontekstu je treba obravnavati arhitekturo in njeno publicistiko tega časa, $\mathrm{v}$ kateri je pogosto težko ločiti med avtorjevim osebnim mnenjem, prilagajanjem novim družbenim razmeram in prevpraševanjem delovanja v novih pogojih.

\section{Literatura}

Bernik, S., Pogledi na novejšo slovensko arhitekturo in oblikovanje, Ljubljana 1992.

Bernik, S., Slovenska arhitektura dvajsetega stoletja, Ljubljana 2004.

Gabrič, A., Slovenska agitpropovska kulturna politika 1945-1952, Borec, VIIL/7-8-9, Ljubljana 1991.

Gabrič, A., Slovenska kultura pod sovjetskim vplivom, Evropski vplivi na slovensko družbo (ur. Troha, N. in drugi), Ljubljana 2008, str. 249-257.

Golomstock, I., Totalitarian Art in the Soviet Union, the Third Reich, Fascist Italy and the People's Republic of China, New York, London 1990.

Grabrijan, D., Naše orientalne i savremena kuća, Problemi arhitekture in urbanizma LR Slovenije (ur. Ivanšek, F.), Ljubljana 1950, str. 105-115.

Ivanšek, F., Za napredek naše arhitekture, Arhitekt, 1/1951, str. 1.

Kadijević, A., Problemi istraživanja i tumačenja socrealizma u srpskoj arhitekturi, Novopazarski zbornik, 30, 2007, str. 211-217.

Košir, F., K arhitekturi. Razvoj arhitekturne teorije na Slovenskem, III, Ljubljana 2007.

12 "Socialist Realism (In the Soviet sense) in Yugoslav architecture died out of its own accord with the removal of the Soviet influence. It should be added that it had enjoyed no real sympathy with architects. [...] today we can say with gratitude that Le Corbusier has filled a whole generation of Yugoslav architects with enthusiasm for architecture. From this source our architecture has developed and although sometimes work tends to become rather stereotyped, insufficiently differentiated and even stiff and badly adapted to our specific conditions, no one can dispute the importance of the part played by Le Corbusier in the development of our modern architecture« (v besedilu objavljen prevod je avtoričin). 
Kraigher, M., K nekim pripombam o arhitekturi na V. Kongresu KPJ, Novi svet, 3/10, 1948, str. 777-785.

Kulić, M., Politika arhitekture. Novi Beograd, Arhitektov bilten, 167/168, 2005, str. 82-87.

Kulić, V., Mrduljaš, M., Thaler, W., Modernism in Between. The Mediatory Architectures of Socialist Yugoslavia, Berlin 2012.

Mordvinov, A. G., Umetnostni problemi sovjetske arhitekture, Ljubljana 1946.

Pavlinec, D., Značaj slovenskega slikarstva obdobja socialističnega realizma, ZUZ, n. v., 40, 2004, str. 221-252.

Ravnikar, E., Maršal Tito našim arhitektom, Novi svet, 2/5-6, 1947, str. 362-365.

Ravnikar, E., Nova državna opera v Beogradu, Novi svet, 3/4, 1948, str. 304-307.

Ravnikar, E., Razstava Sovjetske arhitekture v Ljubljani, Novi svet, 3/7-8, 1948, str. 612-615.

Ravnikar, E., Ob razstavi arhitekture FLRJ v Moderni galeriji, Novi svet, 6, 1949, str. 604-608.

Ravnikar, E., Ivanšek, F., Post-War Architecture in Yugoslavia, Architects' Year Book, London 1955, str. 121-136.

Repe, B., Vpliv zahodnih držav na domači sceni, Jugoslavija v hladni vojni: Yugoslavia in the Cold War (ur. Fischer, J. in drugi), Ljubljana 2004, str. 361-366.

Šijanec, F., Sodobna slovenska likovna umetnost, Maribor 1961.

Šumi, N., Pogledi na slovensko umetnost, Ljubljana 1975.

Tepina, M., Načrtnost terja nove metode projektiranja, Novi svet, 1/1-4, 1946, str. 132-135.

Urbanizem, arhitektura, konstrukcije (ur. Grabrijan, D., Didek, Z.), Ljubljana 1948.

Zaključci prvog savjetovanja arhitekata FNRJ o pitanjima urbanizma i arhitekture, održanog u Dubrovniku od 23. do 25. novembra 1950, Urbanizam i arhitektura, 11-12, 1950, str. 4-13.

Zbornik oddelka za arhitekturo na univerzi v Ljubljani 1946-1947 (ur. Mušič, M., Ivanšek, F.), Ljubljana 1948. 


\section{Martina Malešič}

\section{Z Vzhoda na Zahod - leto 1948 in njegovi odmevi v slovenski arhitekturni publicistiki}

Ključne besede: socialistični realizem, modernizem, slovenska arhitektura, arhitekturna publicistika

Po zaključku 2. svetovne vojne, ko je komunistična partija prevzela oblast, Jugoslavija pa je postala del vzhodnega, komunističnega bloka, je sovjetski družbenopolitični model prevladal na vseh družbenih področjih - od ustave do kulturne politike. Tako kot v drugih kulturnih dejavnostih se je tudi v arhitekturi v prvih povojnih letih sledenje sovjetskim modelom izrazilo v slogu, ki bi ga delno lahko opredelili kot socialistični realizem. Spor Jugoslavije z Informbirojem leta 1948 je vodil do njenega izstopa iz vzhodnega bloka. Prekinitve političnih in gospodarskih vezi s Sovjetsko zvezo so postopoma sprožile rahljanje kulturnih vezi. Petdeseta leta so prinesla zaton socialističnega realizma in ponovni zagon modernizma, ki je v ozadju vztrajal iz časa med obema vojnama.

Prispevek poskuša opisanemu dogajanju slediti z vpogledom v sočasno slovensko arhitekturno publicistiko. Osredotoča se na izbrana besedila, ki se odzivajo na dinamične preobrate znotraj arhitekturne stroke, pogojene s spreminjajočimi se družbenimi razmerami. Na takšen način lahko jasno spremljamo, kako se je v kratkem časovnem obdobju od leta 1945 do začetka petdesetih let, glede na družbeno-politične razmere, spreminjalo sprejemanje in razumevanje socialističnega realizma in sovjetske arhitekture na eni ter modernizma in zahodne arhitekture na drugi strani. 


\section{Martina Malešič}

\section{From the East to the West - The Year 1948 and its Echoes in Slovenian Architectural Publications}

Keywords: socialist realism, modernism, Slovenian architecture, architectural publications

Immediately after the end of WWII, when Communist Party took power, Soviet models prevailed in every aspect of society, from the Constitution to cultural policy. In architecture and other cultural activities there was a noticeable following of Soviet models that was recognizable in use of the style which can be loosely defined as socialist realism. Yugoslavia's dispute with Informbiro in 1948 caused her to leave the communist bloc. The severing of political and economic ties also caused cultural ties to wane. The 50's brought the decline of socialist realism and renewed momentum for modernism, which persisted, though only in the background, from the interwar period.

In the paper I try to follow these developments with insight into contemporary Slovenian architectural publications. The content is focused on a selection of cases which clearly show dynamic turns in architectural profession and which were dependent on changing social conditions. This offers us an opportunity to see how the perception and understanding of social realism and Soviet architecture on the one hand and of modernism and Western architecture on the other changed with social and political circumstances. 